\title{
Familiar Beasts
}

\author{
Nature, Culture and Gender \\ in Wildlife Films on Television
}

\author{
Hillevi Ganetz
}

For most people, animals are symbolic: their significance lies not in what they are, but in what we think they are. We ascribe meanings and values to their existence and behaviors in ways that usually have little to do with their biological and social realities, treating them as emblems of nature's purity or bestiality in order to justify, ultimately, our views of other human beings (Bagemihl 1999:79).

At the core of Western culture, there is way of thinking in dichotomies, of dividing into twos, of constructing binary oppositions, for example, good and evil, male and female, body and soul, feeling and reason, etc. One of the most central and fundamental dichotomies is the one between nature and culture. Like many similar ones, this dichotomy has been discussed and deconstructed in a number of works in the last few decades (e.g. Haraway 1989, Butler 1991 \& 1993, Robertson et al. 1996, Franklin, Lury \& Stacey 2000). But in spite of the fairly large agreement in the scientific community that culture and nature should not be regarded as opposites, but that that they are interdependent and presuppose one another, the idea of an opposition thrives. This is not the least true in the media, where televised wildlife film is an interesting example of how the dichotomy nature/culture is constructed and reproduced. ${ }^{1}$

In Western thinking, nature is associated with woman, and culture with man. Ideas about nature, culture and gender are always connected. The construction, 'making', or creation of gender takes place on all levels of culture and society, and consequently also in the media, which simultaneously contribute to, and reflect this process. In the present article, I will analyse how gender, linked to the cultural construction of the nature/culture dichotomy, is created and reproduced in wildlife films.

So, why is it important to study the construction of nature, culture and gender in the media, and specifically in wildlife films? Today there is a lively discussion about the formative influence of culture and society on gender and sexuality, where biology is supposed to represent what is 'natural' and culture 'unnatural'. A number of often traditional opinions about women's and men's work, care of children, homosexuality, adoptions, morality and family formation are brought forth with reference to nature. But in actual fact, the life and sexuality of animals are as varied as human life and sexuality. This fact is, however, surprisingly little known outside academia, and wildlife films not 
the least have contributed to the concealment of this literally natural heterogeneity, something that is going to be discussed below.

Media in general give different, sometimes opposing, versions and images of masculinity and femininity, but these constructions of gender, are seldom taken up for discussion in media discourse at a conscious, reflexive level. Although gender is constantly produced and reproduced - in news, soap operas, game shows and documentaries - there is little awareness that this is what is done. The media offer is characterised by what I would like to call gender routine, that is, habitual, instinctive, unreflecting and iterated accounts of masculinity and femininity. Gender routine is not the result of a conspiracy; it is instinctive and maintained by both women and men in the media. It is 'invisible' in the way that it does not, for example, contain sensationally sexist images - which are of course easily detected - but based on habitual and unreflecting iterations of culturally and socially produced ideas about masculinity and femininity. ${ }^{2}$ There is also gender routine in wildlife films, as well as routine accounts of, for instance, ethnicity and sexuality.

It must be emphasised that wildlife films have done much to call attention to environmental issues, and to spread important knowledge about animals and plants. What is critically analysed in the following is not their important achievement, but the routine neither obviously racist, sexist, nor homophobic - that colour wildlife films. It is the routine that characterise media accounts in general, and the material that I have investigated in particular, in 14 films of varying length, starring lions and elk - in some places, popularly known as the King of Beasts and the King of the Forest respectively. All films were shown on Swedish public service television, SVT1 or SVT2, between 1979 and 2002 (see appendix).

\section{Wildlife Films: Science and Entertainment}

Since its appearance in the beginning of the last century, wildlife film has been characterised by two fundamental phenomena in Western civilisation, namely science and entertainment (Mitman 1999: 5ff; Bousé 2000: 57ff). Science started to use film around 1900 in order to communicate its findings to people outside the universities, but it was to a small, limited, and well-educated elite. At the same time, the movie industry developed in the US, and one of the first 'wildlife films' was Roosevelt in Africa, which opened in cinemas in April 1910 (Mitman 1999: 5). It was a so-called hunting film, starring the former US president, based on a yearlong expedition during which 40 animals were killed per day. ${ }^{3}$ In other words, commercial wildlife film addresses its audience in a more thrilling and entertaining way than science film, but it has leaned - and still does lean - heavily against science to substantiate its aura of authenticity, which has been, and still is, so fundamental for its claims to realism, didacticism and objectivity.

The tension in wildlife film between the demands of authenticity and entertainment has been a constant through history, and there have been discussions in the business about how much fact and how much entertainment is justifiable, where the line between the two goes. Some - especially those with close ties to science - have wholly rejected the 'entertainment aspects', for example to turn a specific material about gulls into a linear narrative at the editing table (Mitman 1999: 67). Others have not minded creating dramatic climaxes by provoking fights to the death between animals that have been kept locked up in separate cages for several days without food. This was done, for instance, in the feature film The Silent Enemy, which was first screened in 1930, directed by William Douglas Burden (Mitman 1999: 47). This example is of course an extreme, and 
does not represent what most wildlife filmmakers have done, and still do, but it says a lot about the tensions between authenticity and entertainment in the genre.

The importance of science for wildlife films can be studied from several angles. One is to compare the representation of the sexuality and social formations of animals in wildlife films with findings in the sciences. The American biologist Bruce Bagemihl (1999) does not analyse wildlife films, but looks at how findings about the highly varied sexual and social practices of animals are concealed, or more euphemistically reformulated, in science in line with contemporary cultural notions about what is 'natural' and what is 'good' behaviour. His work is an important basis for understanding representations in wildlife films of the sexuality and family formation of animals.

Begemihl describes the long-standing taboo about even mentioning the diversity of animal sexual practices. He has gone through a considerable amount of zoological research. He concludes that it is clear that the diversity of sexual practices among animals has been concealed or silenced, and that it is the scientists themselves who have not dared to publicise their results because of the risk of being stigmatised as homosexuals. This fear was obviously more prominent 50 years ago. In more recent biological research it has been possible to acknowledge the varying sexual practices among animals, but now the problem is, according to Begemihl, the way scientists interpret these practices.

He thinks that scientists interpret same-sex acts as 'mistakes' since it does not lead to the propagation of the species, which is so central in evolution theory - that is, they view it in the same way that many people see human homosexuality. That it is not quite that simple has been discussed by, for example, the zoologist Paul Vasey (1995), who has made extensive studies of primates, for instance Japanese macaques (cf. Snaprud 2003), and who argues that same-sex acts cannot be explained in any other way than the animals do it because they actually like it, that is, it is not a mistake. At the same time, this behaviour should not be interpreted as homosexuality. Animals are not homosexual in any human sense; they do not have a stable preference for their own sex. But they are involved in sexual practices that resemble homosexuality, or rather, bisexuality. But what should we call these practices? There is simply no language for the same-sex practices found in nature, an interesting fact in itself (cf. Bagemihl 1999: 12). Animals are not homosexual in any human sense, nor are they heterosexual. Lacking better terms, and because the need to talk about these phenomena in the following, I will sometimes still use the human terms, despite the anthropomorphism, which I will later criticise in relation to wildlife films.

Bagemihl (1999) argues that animal sexuality and 'family formation' have been interpreted within a human ideological and moral framework. In other words, humans first determine what is considered 'natural', then this 'naturalness' is applied to nature, and last this construction is used as a proof and argument against things 'unnatural', for example, homosexuality or women who do not stay home and take care of their children. It might not be necessary to point out that these things are found in nature, just as sexual acts between individuals of different sexes, and females who take care of their offspring. Bagemihl's point is, however, that the many and frequent 'deviations' (which of course are not deviations) have not been made visible in the sciences and that 'normality' (which is not normal) has been emphasised.

The consequence for wildlife films is that in their accounts of animal sexuality there are not many deviations from 'normality'. But the whole blame for this blind spot in relation to varying sexual practices cannot be lain on the dependence on biology in wildlife films alone. Wildlife film does not only have a science side but also an entertainment side. As 
part of mass culture, wildlife films have to be sold on a market, and in order to attract consumers on this market they have to adapt to prevailing moral and ideological positions. Until the late 20th century, wildlife films could not show too 'shocking' scenes, such as detailed violence (animals who kill and eat one another in too graphic and too long scenes) or extensive depictions of sexual intercourse. On the other hand, in the 1990s something that might be called snuff wildlife films appeared, showing close-ups of animal violence (Mitman 1992: 208). Of course, this trend in wildlife film is connected to the same development in the entertainment industry in general, where violence has become more common in films and on television. But it would last until 1995, before possibly the first pictures of animals involved in same-sex acts were shown (Bousé 2000: 175f).

But it is the puritan trait that dominates the history of American wildlife film, with Disney's series True-Life Adventures as a fine example (Mitman 1999: 109ff). In the end of the 1940s, Disney started to shoot short wildlife films to be screened in cinemas. These films emphasised the individuality and personality of animals in order to, in Disney's words, 'help the audience to sympathise with it [the animal] and understand its problems better' (Mitman 1999: 119). The anthropomorphism in these portrayals of animals took its lead from Disney's experience with animated cartoons such as Bambi from 1942. At Walt Disney Company, it was thus the animated cartoons that gave rise to wildlife films and not the other way round. The music, which is also a trace from the animated cartoons, was also going to play an important part in wildlife films. For example, a sequence in the film Seal Island (awarded an Oscar in 1949) showing female seals coming to a beach is accompanied by variations on 'Here Comes the Bride' (Mitman 1999: 110).

The American 1950s were characterised by an ideology that put family and God at the centre - in other words, not very unlike the situation in the beginning of the 21 st century. Walt Disney himself subscribed to this ideology and helped to disseminate it to broader layers of the population, repeatedly celebrating 'eternal values' in films made for mass audiences (Mitman 1999: 125). In his wildlife films, nature appears idyllic, a tapestry showing animals living in harmony with one another and thriving under the rigid but benevolent supervision of God. The smallest unit in this world is the family, for example made up of 'mummy bird', 'daddy bird' and their kids. In one of the films, for example, it is said that, 'In nature's half-acre, motherly love is expressed in patience and devotion. Be it fair weather or foul, mother always stands by' (Mitman 1999: 127). Of course, violence and sexuality played no part in this image of nature. Yet the censors in New York and Maryland asked Disney to cut a sequence in a film that showed the birth of a buffalo calf because, naturally, the sexual organs of the female buffalo could be seen (Mitman 1999: 130).

\section{Wildlife Film on Television}

With television, the animals in wildlife films become domesticated, and the characteristic format nature programmes is created. In American television's first and most successful nature programme, Zoo Parade (NBC, first season in 1950), which was aimed at the whole family, showed various animals as cute, cuddly and nice friends who were sometimes even smarter than humans. Zoo Parade was paid for by pet product advertisers. This market grew considerably after the war as pets became part of the nuclear family. Box office successes in the 1960s such as Born Free and Flipper are developments of a phenomenon that Mitman (1999: 157) calls the 'Pet Star', but in the latter film there is of course not one frame that shows the aggressive, ample and androgynous sexuality 
of dolphins, which science and wildlife films have never said anything about (cf. Bryld \& Lykke 2000).

But there is another factor in the development of wildlife films in this period, that is, the rise of mass tourism (Mitman 1999: 180ff). The nature programme Wild Kingdom (NBC, first season in 1963), which succeeded Zoo Parade, focused on adventure, wilderness and male virtues, things found in another 20th-century invention, the national park. Wildlife films became advertisements for such tourist attractions, in America and elsewhere. In the 1950s and 1960s, Western and educated voices were heard saying that the wilderness in Africa was threatened. They complained about the consequences of the civilisation that they had been so eager to introduce for themselves, and thought that nature must be protected from it, or as the ethologist Julian Huxley said: 'Africa's wild life belongs not merely to the locals, but to the world' (Mitman 1999: 194). One can talk of a kind of wildlife imperialism, where animal life and nature is taken from the indigenous African population. In this propaganda war, wildlife films played an important part. In for example the film Wild Gold (1961), directed by James R. Simon, the Masais were portrayed as a threat to nature since their cattle took food and water from the wild animals in the national parks. But according to the narrator they would soon enough learn that no true wealth comes from hordes of useless cattle, but through tourism (Mitman 1999: 198).

In Swedish public service television - which is the subject of the present study - the first wildlife film was broadcast as early as 1955. It was Viggen Viggo ('Viggo the Tufted Duck') by Bertil Danielsson, which incidentally gave Swedish television its first international award, the Prix Italia in 1957 (Furhammar 1995: 87; Abrahamsson 1999: 51). In June 1961, the nature programme Just nu ('Right Now', a.k.a Korsnäsgården, after the location it was shot at) started and was continually broadcast until 1984. It was hosted by three Swedish gentlemen in 'chequered shirts and rubber boots', namely Nils Linnman, Anders-Erik Malm and Gert Engström (Abrahamsson 1999: 51). Naturrutan ('The Nature Screen') was shown on SVT1 between 1974 and 1987 and Ett med naturen ('One with Nature') was broadcast on SVT2, 1983-1996. There have also been a number of films and film series by Jan Lindblad, David Attenborough, Desmond Morris, Arne Sucksdorff, Bo Landin, Sven Gillsäter, and others. But the history of wildlife film on Swedish television has not yet been written, nor has it been analysed. Within the framework of the Swedish Broadcasting Media Project, both Leif Furhammar (1995) and Ulla B. Abrahamsson (1999) have written short surveys of the nature programmes on Swedish television, but they are found in volumes where nature programmes are only minor parts among 'Documentary Programmes' and 'Factual Study Programmes', which are the headings of the reports where the history of the nature programmes appear.

The current Mitt $i$ naturen ('In the Middle of Nature'), the heading for the nature programmes that Swedish television's Sundsvall studio produces in northern Sweden, has been broadcast since 1980. What is shown there can be divided into two rough categories: on the one hand, purchased material produced abroad, and on the other hand, the viewers' own films and videos. The first category of films is shown as Mitt i NaturenFilm, broadcast during peak viewing hours (in the spring of 2003, on Tuesdays at 8 p.m., SVT2) and consists mostly of films showing exotic animals, plants and environments, produced by companies such as the BBC and National Geographic - the two international giants in the business. Mainly because of a lack of money, the in-house production in Swedish public service television is small. The viewers' own films are shown in a halfhour segment in the middle of the week (in the spring of 2003, on Wednesdays at 8 p.m., 
SVT1) and portray 'everyday wildlife', that is, Swedish animals, plants and landscapes, shot by amateurs and semi-professional filmmakers. Every year, the best film by a viewer is awarded the 'Golden Lynx'. On average, each show has 8-10 percent of the Swedish viewers, that is, around 800,000 people. $^{4}$

Also internationally the literature on wildlife films is surprisingly small. But Derek Bousé (2000), who analyses both the production technology and aesthetic/formalist side of wildlife film, and the historian of science Gregg Mitman (1999), who writes a history of ideas of American wildlife film, are two important American exceptions. Neither has a salient gender perspective, however. It is Mitman who provides the facts that I opened the present article with, namely, that from its beginnings in the early 20th century, wildlife film has been characterised by the demands of science and entertainment, and the ways they have affected the descriptions of animals and nature. Derek Bousé emphasises the entertainment side in his account. According to his analysis, wildlife film narratives are heavily influenced by Hollywood film and by television fiction (for example, melodramas and soap operas), which makes him conclude that wildlife film is a pseudo-scientific and pseudo-documentary genre (2000). From Derek Bousé's perspective, the contexts in which Leif Furhammar's (1995) and Ulla Abrahamsson's (1999) studies have been placed are misleading, since they are found in two volumes that account for documentary programmes and factual study programmes on television and radio. Their surveys would have been just as well suited for a work on television fiction, since there are strong reasons, according to Bousé, that the wildlife genre's claim to represent nature authentically should not be accepted.

\section{Nature in Wildlife Films}

In his large survey of Western attitudes to and definitions of nature, from the ancient Greeks to the present, the historian Peter Coates (1998) underlines that what has been regarded as nature and culture has varied through history. An enlightening example is the different places that man has been given in relation to nature and culture. For example, before Darwin man was seen as the image of God (that is, as culture), but after Darwin man became the closest relative of the apes (that is, a bit closer to nature). People have always interpreted nature, both in and outside the sciences. ${ }^{5}$ There are no 'pure', objective depictions of nature, only interpretations that depend on the historical, cultural and social contexts. Judith Butler (1991: 37f) argues that what is defined as nature in relation to culture is in fact already culture, that is, it is culture that determines where the border to nature is drawn. There is thus no 'objective' line between the two, and they are all the time defined through various practices, resulting in different representations of nature. ${ }^{6}$ One of these representations is wildlife film.

On a primary, immediately observable level, wildlife films are narratives about nature. But on a more concealed level, they are just as much narratives about culture, since these two phenomena suppose one another, like the two sides of a coin. An example of the way in which Western culture influences representations of nature is found in the accounts of lions and elk, being the subjects of the films analysed in the present study.

Not the least the claim that the Western production context is significant for the way elk and lions are portrayed is clear from the accounts of the relations of the animals to humans. Elk are shown in such relations more often than lions. The subjects of two of the films are even tame elk who move around indoors and behave like pet animals. Almost all elk films mention, and some even deal exclusively with, elk hunting, and then 
from a human perspective (or more specifically, a human male perspective). The perception of the elk is that it is everyday, nice, almost comical animal, intimately connected with the life of people - even eaten by people. The elk is a Western, 'safe' animal, wholly in the control of man. In the example below, a short film from 1959 (1997, SVT1), an elk is so much part of the life of a group of people that it has become a member of the family and 'thinks' like a child. Also note the prejudice about curious women, which is partly taken back by the speaker, suggesting the kind of dawning but not completely rooted awareness of the equality between the sexes that is characteristic of the time:

Black-and-white pictures. 'Brisk' music typical of the SF newsreels [the Swedish Film Industry Co. Ltd.]. An elk calf with a dog collar enters a dwelling house with rag mats on the floor and hens running about. The male narrator calls happily and enthusiastically: 'Well, well - today there are apples on the menu. What a treat!' The elk eats apples from a box. Cut to two on-looking dachshunds, who according to the narrator 'think': 'Green forage, when one can get bones. She's hopeless.'

The elk saunters to a breakfast table: 'What will Master have? Tomatoes!' The elk eats the tomatoes. Turns over an egg. Eats the flowers in a vase. 'Here's something that is served in an appropriate way.' Cut to the dogs, who look 'embarrassed'.

The elk peers into a cupboard. The narrator: 'And here is the explanation why Nosey Parker is called Nosey Parker. She has to look everywhere. She is curious like a woman... well, sorry, like a man. She has to inspect everything.'

Pictures of a couple of legs in boots entering the room. 'Please, Nosey, not the pantry!' 'Well, here comes Master. Good morning! How are you today, Sir! Oh, really? I dare say, Sir, it is not easy to know how to behave when one has been raised without a mother.'

Nosey Parker turns on the radio with her muzzle and 'listens' to the weather forecast - her ears moving constantly: 'Continued warm and good weather', a voice says from the radio. She lies down on a mat. The narrator: 'Well, that sounds good. Then I can relax, says Nosey Parker.'

In the Western wildlife films in my material, lions are represented in a completely different light. They are not pets that children could cuddle with. If anything, in relation to lions people are humble, admiring and grateful in a whole different way than in the relation man/elk. This is of course due to the fact that lions are potentially dangerous predators and the elk is a ruminating deer, but it is just as much a question of making the lion exotic and mythologising it in a way that is very ancient in Western culture. If the humans who are neighbours to the lions in Africa and India would make films about lions, they would probably not have the same admiring and humble attitude and there might also have been lion hunting, which is not shown in any of the Western films in the material. A beautiful example of the admiring position is a film by Jan Lindblad about Indian lions from a series of films called Djungelbokens värld ('The World of the Jungle Book', 1980, shown on SVT1 in 1993 among other times).

Pictures (colour) of a female lion with suckling cubs, dusk, crickets, the sound of howling. No music. Jan Lindblad's voice: 'First the cubs will have their evening meal. It feels amazing to sit in the grass just four or five meters from this lion trio. By now we have won their trust.' Cut to a picture of a male lion yawning. 'And also the trust of the two males. Step by step I approach them and come 
incredibly close, less than two meters. Again it is a question of trust - between a wild lion and me, a representative of a species that has been its lethal enemy for centuries.' Close-up of the male, only showing his eyes. Cut to a beautiful red sky with black trees in the foreground.

'The sun sets and I had an idea of showing the sunset as a reflection in the eyes of the male lion.' Extreme close-up of a lion's eye where the setting sun is reflected. 'You probably can't get any closer to the wild than this. It is a wonderful privilege to be accepted.'

To show the sunset as mirrored in the eyes of an elk would seem almost comical, the equivalent of third-rate art portraying an elk at sunset. In Swedish culture, the elk, known as the King of the Forest, represents Swedishness, commonness and a kind of wild safety. In combination with a romantic trait, the relation with this animal easily becomes highflown and pretentious. The lion, on the other hand, is exoticised in Western culture - the orientalism that Edward Said (1978/1991) deconstructed survives in the image of the lion - and is easily coupled with romanticism. It has to be added that it is symptomatic that it is a lion that is filmed in extreme close-up, a technique that is used to create a feeling of closeness and intimacy between the viewer and the viewed (Bousé 2000: 29). There is nothing romantic or heroic about a close relation with an elk, as with a lion. In Western mythology, the lion - almost always a male - symbolises might, courage, majesty, justice and law. And these are just some of the characteristics that are ascribed to the lion and which can be found in any symbol dictionary. These animals may not be patted or killed in contemporary wildlife films, just be admired. ${ }^{7}$ Both species are interpreted within a Western cultural context, which results in an ethnification of them, that is, the animals are inscribed in a highly human, collective, cultural identity.

Nature in wildlife films is constructed by being defined in opposition to culture. One of the strategies of delimitation is characterised by a concealment of the fact that wildlife film is one genre among others. This is done by concealing the fictive traits and the dependence on technology in the genre.

Bousé (2000: 20) demonstrates that the acknowledgement of wildlife film as a distinct television and film genre involves the acknowledgement of the fact that it is not a documentary genre, but fiction. He gives many examples of the close affinity of wildlife films to fiction: one is the construction of a central and repeated narrative in one wildlife film after another. Above all, this narrative takes shape on the editing table, and can summed up in the sequence 'birth, school, work and death', a formula with deep roots in Hollywood film (Bousé 2000: 174ff). Still, he thinks, many people in the wildlife film industry insist on defining wildlife films as films that show wild animals in their natural habitats, that is, as 'pure' imprints of nature. If this were true, he says with a poignant example, a one-hour film about the life of lions would contain more than 42 minutes when the lions do nothing, since lions rest more than 20 out of 24 hours (Bousé 2000: 7). Nor would wildlife films contain as many (well-concealed) corrected and constructed moments as is the case. In the industry, it is well known that wildlife films produced in America often contain scenes shot in sets with tame animals. Wildlife film produced in Sweden, on the other hand, has had a reputation for not arranging scenes or manipulating the viewers, a tradition originating with and having a fine representative in Jan Lindblad. But since the middle of the 1990s, it has also become more usual among Swedish wildlife filmmakers to 'help' nature along. In the film Laponia by the production company Scandinature, the lemmings shot under the snow are (more or less) tame, and 
in the ensuing scene they are filmed in an artificial mountain scenery built in the filmmaker's own garden outside Stockholm. To shoot water freezing in the film Taiga: Forest of Frost and Fire varnish was heated with a hair dryer on a windscreen, and when the summer arrives heat haze was created with a gas grill (Nilsson 2000). These are just a few examples of departures from the ideals of 'wild animals' and 'natural habitats'. On closer inspection, we see that wildlife films can be defined as a construction of wild animals and nature that is made invisible for the viewer. There seems always to have been a more or less agitated discussion within the industry about the moments of construction that wildlife films always contain, but unfortunately the issue has not been discussed openly with, or before the audience. The lack of an open discussion has made us, ordinary television viewers and cinema goers, believe that wildlife films, whether more 'scientific' or more 'entertaining', are authentic and realistic imprints of nature.

A wildlife film is never nature; as soon as someone observes and depicts nature with the help of technology, a step is taken away from nature to culture (if it is possible to distinguish the two). The camera and the sophisticated technique that is needed to capture animals on film are made invisible in wildlife films today. This invisibility, which can be called 'immediacy' with Bolter's and Grusin's term (2000), is distinctive for all visual genres, but transparency and authenticity becomes particularly important to uphold in wildlife films, whose status rests on the view that it is a documentary genre. Bolter and Grusin also point out that immediacy is interwoven with hypermediacy, that is, a strong fascination with the mediation process as such that manifests itself in explicit references to media forms and genres, so that the constructedness of the media text is emphasised. Visible technique is not unusual in wildlife films, especially older ones. In one of the oldest lion films in the material (1979, SVT1), a Japanese camera crew is followed who document a lioness and a male lion during a year, through transmitters fasten around the neck of the animals. The camera work and the filmmakers are clearly shown in relation to the animals. But the ground for the incessant display of technology, here, is not a fascination with the mediation process and an emphasis on the media text as construction - on the contrary. The visible technology is here a sign of realism, underlining that 'this has happened and is true'. This kind of realism seems antiquated today: instead, at the moment, it is sophisticated, hidden technique that can sneak close to the animals that signals realism.

The frequent use of music might seem even more contradictorily. The sound track breaks the illusion of pure nature, but links wildlife films closer to entertainment. This is often counterbalanced by selecting music that would be sorted under the heading 'New Age' in a record store - a kind of music consisting of ethereal and thin tones. Aggressive instruments such as trumpets and electric guitars are unusual, as are fast, bustling rhythms. Nor are there ever any lyrics; if human voices can be heard they hum wordlessly - if they are not African, since then the lyrics will be in languages that Western viewers do not understand. An 'ethnic' sound dominates: native American and African drums, wooden flutes, acoustic instruments or dreamy synthesisers. The choice of sound and instruments may of course be explained by a desire that the music have a relation to the place - a film from Africa should thus sound 'African'. However, 'traditional', 'ethnic' instruments do not associate to contemporary Africa but connects the music to ideas about 'primitive people'. In this way, there is an attempt at creating something that can be associated to 'natural' music - which of course, like other lines drawn between nature and culture in the films, is a construction. 
Another element that is typical of wildlife films that has to do with the line between nature and culture is anthropomorphism. Here also, Disney is a forerunner. In the end of the 1940s, modelled on animated cartoons, Disney started to shoot short wildlife films where the individuality and personality of the animals is stressed. However, what was shown was not the real life and behaviour of animals, but highly arranged versions. In wildlife films, animals are above all made human in the voiceover, where they are given feelings such as hope, happiness and grief. A clear example of anthropomorphism is found above in the example of Nosey Parker, the elk, where both the thoughts of the dachshunds and the elk calf are interpreted by the narrator. But there are also examples of anthropomorphism in the television announcers' presentations of the films, such as in this one from 1997 for a lion film: 'But behind the majestic facade, every lion has his own private life, full of drama, joys and tragedies' (1997, SVT2). Overall, the 14 lion and elk films do not contain very many startling examples of anthropomorphism, but are more characterised by routine where human norms and morality (invisibly) colour and organise the presentation of the animals. The reason is of course, as Bousé (2000: 5) shows, that the point of wildlife films is to present something that viewers recognise, something that they have the conceptual tools to understand, for example when a group of elk are described as 'A general meeting at the gentlemen's club, a meeting of as many as ten tall bull elk...' (1999, SVT1), or when a lion's rough treatment of its cubs is accompanied by the words, 'when it comes to bringing up children, lions belong to the old school and impose discipline' (2002, SVT2). Anthropomorphism is today so naturalised and institutionalised in wildlife film that it seems 'natural'.

Further characteristics of the way that lines are drawn between nature and culture in wildlife films is the absence of humans (Bousé 2000: 15). People are not 'nature'; they are 'culture' in too great a degree, and threaten to destroy the pretension in wildlife films of providing pure impressions of nature. This is why a great deal of energy is spent on cutting out scenes where film crew mistakenly stray into scenes, or pictures of tourists and tourist hotels that are so common in the African national parks, where many of the wildlife films are shot. For example, one of the lion films in the studied material is shot in Kenya, in a national park which is visited by 700.000 tourists every year, without even one tourist appearing in the film.

However, it might seem that there is an opposite trend in wildlife films at the moment, since several prized wildlife films have been made where man, and not animals, has the principal part. One example is Vision Man from 1997, which is an account of an old Inuit and his memories of hunting. At the International Wildlife and Environment Film and Television Festival in Bristol in 2000, the trend was reinforced with a wildlife film that sensationally won first prize and is about a 'primitive' people in Africa that hunt in a similar way as the big wild cats. It might seem that the line between nature and culture is dissolving. But the truth is probably that an old and highly questionable trend is growing stronger, a trend that equates nature and certain human races (Mitman 1999: 44). Historically, in wildlife films white people have not appeared if they do not in some way master nature, for example with the camera (cf. the above example with the Japanese lion film) or take the part of experts or presenters explaining nature. On the other hand, native Africans, for example, have been very rare in other roles than bearers in old safari films, or as parts of the landscape in more recent ones. Those who have now become main characters are so-called primitive peoples who are not supposed to represent culture but nature in line with a Western conservative view of the difference between 'primitive' and 'civilised' peoples. 


\section{Gender and Sexuality}

Wildlife films are not only constructed around a dichotomy between nature and culture, but also between the sexes - 'male' and 'female'. Many animals (but not all) belong to one or the other of the biological sexes, but gender, or the cultural division into male and female, is something that humans create in their narratives about nature. Connected to gender, sexuality, 'natural' and 'unnatural', is also a running theme in wildlife films. Or more to the point, 'natural' sexual acts between the sexes are shown while the 'unnatural' is characteristically absent. In the elk and lion films, there are ample illustrations of Judith Butler's thesis that in the same way as culture defines nature, gender defines sex, heterosexuality homosexuality, and normality what is not normal (Butler 1990: 65, 74, 77 \& 1993: 111, 206f).

But if the line between nature and culture becomes visibly noticeable in the films, gender and sexuality are mainly manifest in the voiceovers. Language structures our perception of reality. A very naive but widespread view of language is that it can reflect so-called reality. In a socio-cultural perspective, words do not reflect 'reality' but the way various phenomena are looked upon in a culture. Language can thus be said to express ideas that are specific for a culture at the same time as it creates the same culture. Language works as a grid that helps people to organise the world and make it meaningful, at the same as it limits it, since some phenomena are named while others are never expressed, for example the 'homosexuality' of animals. That language works as a cultural grid also becomes obvious in the use of the concept of 'family' in wildlife films. A cow elk with two calves are called a family, since they resemble the human, Western, conventional nuclear family. On the other hand, a group consisting of up to a dozen female lions with cubs and a few male lions who have 'married into' the group - which is the normal social constellation that lions live in - is not called a 'family', but a 'pride', although the formation constitutes the family of lions. On a superficial level, this usage might seem a way of avoiding anthropomorphism, but at a deeper level, the distinction between 'family' and 'pride' implies a projection of human norms and ideals onto animals. In this example, one could just as well call de group of lions a lion family, but the human and Western norms of what constitutes a familymummy-daddy-kids - prevents it.

In the 14 analysed films, there are hardly any sexual acts between individuals of the same sex, which in part can be explained by the great dependence in wildlife films on science. As was shown above, Bagemihl (1999) argues that neither in biology are other sexualities than between two beings of different sexes thematised, despite the fact that, for example, male lions have been observed involved in same-sex acts. An equally important partial explanation of this absence of same-sex practices is that wildlife films, like all television genres, are cultural representations, created within the entertainment industry. As such they reflect and maintain the norms and morality that characterise the culture and society in which they are made. And one of these norms is that family entertainment should not contain 'abnormal' sex. It is the absence of other sexual practices than between two animals of different sexes which is the routine in the analysed films. By habitually, repeatedly and unreflectingly only showing sex between individuals of different sexes in wildlife films, other sexual practices are made invisible despite their frequent occurrences in nature.

But there are a few exceptions in the material. One example is found in a film about lions that was broadcast on SVT1 in 1997: 
Savannah (in colour), two female lions (no music, only the sound of birds and occasional roars). Narrator: 'Life goes on for both females. Four weeks after she lost her cubs, the middle female will be in heat again.' One of the females fusses about and rubs against the other female. They snap playfully at one another. 'Because there are no males around, she approaches the young female. But she does not understand what is going on', the narrator continues.

Here two females are involved in sexual activity with one another - in a way that is fairly common among lions according to Bagemihl (1999). ${ }^{8}$ But the narrator interprets this behaviour according to heteronormativity: the middle female is in heat and 'because there are no males around she approaches the young female'. Here the pictures show same-sex behaviour, but it is interpreted and put right according to human notions as a 'mistake'. The opinion that 'lesbianism' only arises when there are no available men is projected onto animals. To return to Butler (1993), this is an interesting example of gender as performative: the lion's 'sexual identity' is constructed when one repeats what is assumed about sex/gender in the heterosexual hegemony or discourse.

Finally, a couple of examples of how gender is constructed in wildlife films. One of the films show a lion family consisting of five females with cubs and two males (1997, SVT2). The fact is that, it is the females who do the vitally important hunting, often together, while the function of the males is to be breeders, and to fight male lions who turn up looking for a new family. Still the two males in the film are called 'leaders', although it is highly questionable who is leading whom in the lion family. The use of the term 'leader' works to save the honour of a masculinity that is traditionally defined as active, while femininity is defined as passive. This is projected on the lions, and although the pictures show something else the males are inscribed as active while the females are described as passively led. ${ }^{9}$ Another example is the film Born to Be King (1979, SVT1). In the opening, the title is superimposed on a scene in which a lion hunts - a female lion. Obviously, the filmmakers have not found any pictures of hunting males (since they seldom hunt), and instead of calling the film Born to Be Queen, the female is made to 'act' the part of the male, with the purpose of maintaining the cultural construction of the male lion as king, that is, as active, leading and commanding. This is also in line with the epithet of the lion, King of Beasts, and also in many places the elk is known as the King of the Forest. Already these very old names reflect the power of gendered figures of though to create meaning: if the elk and the lion are the rulers of the forest and of the other animals, they are also evidently male. The view of the male animal as the norm, and representative of the species is also settled in the children's television program Varra vild djur: Älgen ('Our Wild Animals: The Elk', 1997, SVT1) where the cow elk is made invisible in the beginning with the claim that the elk (which is a neutral name for the species in terms of sex) 'has a magnificent crown and is the largest deer on earth. He is called the King of the Forest.'

\section{Concluding Remarks}

The questions that have appeared in the analysis of the 14 films deserve answers that are grounded in a material with greater breadth and depth. In the present article, I have looked at films but not their contexts in the nature programmes. Is the gender routine found in the practices of the programme hosts, and in what ways do they reinforce (or contradict) these wildlife films? Does gender routine, like images of ethnicity and sexuality, change with time? Are there differences or similarities as to gender routine between, 
for example, films produced in Sweden and films produced by National Geographic? What are the explanations for these differences and similarities? In order to answer such questions, a larger material is required, also extending over a longer period of time.

It would also be rewarding to study the production process. Is gender routine created already in the field when the choice of what to film and what not to film is made and how? Or is it at the editing table that gender routine comes into play? And what part does the ideologies of contemporary film industry in general and scientific findings play in the concrete work on a specific film or nature programme on television? These are just a few of the questions that can be raised from the limited analysis of wildlife films presented here.

The fourteen wildlife films contain several examples of routine interpretations of the behaviour of animals, in habitual, instinctive, unreflective and repeated accounts of animals that correspond to human norms and morality. This is done both in terms of content and form. For example, through the way the narrative is constructed, in the voiceover or in the editing. Thus conventional gender patterns are maintained in what I call gender routine. It also works together with other stereotypes, among which I have touched upon notions of ethnicity, sexuality and family formation. Behind a testimony that wildlife films show 'true', 'real' nature, animals are given roles and functions that are completely determined by human behaviour and cultural stereotypes. The lion and the elk are ethnified: one animal as a romantic king of his pride and the humans, the other animal as the wild cousin of our pet animals and man's subject. Homosexuality is described through its absence as divergent and unnatural, while the nuclear family and heterosexuality are emphasised as the norm also among animals. Male animals are given a masculine identity that is active and dominant, while female animals are said to possess a femininity that is passive and inferior. These constructed 'images' of animals and nature may then be used as arguments in debates about what is 'natural' femininity and masculinity, to say nothing about 'natural' sexuality. Nature is first culturalised according to human norms, and then this version of nature is used to naturalise the same norms. This process might be described as a cultural boomerang, since it both starts and ends in the hands of man, passing in a wide circle through 'nature'.

The biologist Marlene Zuk (2002) argues that findings about the behaviour of animals have been turned into stereotypes and been misused, both within and outside science. The behaviour of animals may, however, be used to understand people, she claims, but then biology must become the science it really should be, namely a discipline that does not draw a line between the sexes, but neutralises and challenges this line. This demand should also be directed at wildlife films: to correspond to the claims of being an objective, factual and documentary genre, it should also reflect the enormous variety that is found in nature regarding gender, sexuality, and social formations, and thus contribute to the challenge of borders rather than their reproduction.

\section{Notes}

1. Henceforth I will use the label 'wildlife film' to refer to long accounts and narratives shot with film or video, in which animals and nature is the focus. I will use the term 'nature programme' for the programme format on television in which wildlife films are parts, together with reports, interviews, etc.

2. The notion of gender routine comes from Judith Butler's idea of gender as performative, that is, that gender identity is created through iteration of a sex/gender role according to the heterosexual hegemony or discourse (Butler 1993: 122, 232). The concept of performativity is based on the idea that gender is also sex, that sex is just as constructed as gender. The notion of gender routine, which in light of 
Butler's theories of course is a simplification, is here used to capture the characteristic way in which media represents gender.

3. Bousé (2000: 46) notes that as early as 1910 three major categories of proto-wildlife films - Safari Films, Scientific-Educational Films and Narrative Adventures - were all established.

4. See Swedish Television's public service statement of accounts 2002, table 22.6, about the portion of the population who had seen a program from Swedish public service television, SVT, during an average week. In the ten weeks between September 30 and December 8, 2002 on average 9.1 percent saw Mitt $i$ naturen (Wednesdays) and 8.3 percent saw Mitt i naturen - film (Sundays), which can be compared to the 5.9 percent of an in-depth news and politics commentary programme such as Agenda (Sundays), categorised as a 'Politics and Society Programme' by SVT, or the 2.0 percent of a music programme such as Studio Pop (Wednesdays), categorised as a 'Culture Programme' by SVT. Nature programmes are categorised as 'Factual Study Programmes'.

5. In their seminal study, Latour and Woolgar (1986) show how science is 'made' also in the laboratories. Latour and Woolgar use participant observation on scientists and discuss the ways in which they construct scientific knowledge. Science is formed in the discussions among scientists, where for example social hierarchies and rhetorical strategies are decisive for the final interpretations of observations that are made in the laboratories.

6. Cf. Rothfels (2002), where a number of representations of animals are described, though not wildlife films. This volume presents analyses of animals in literature, in art, the construction of the 'fox' in British fox-hunting, how the history of the cloning of a pet animal is represented on the internet (The Missyplicity Project), etc. See also Burt (2002) about the representation of animals in feature films.

7. This romantic view of lions seems to have grown stronger in the course of the 20th century. In the early hunting films, for example Roosevelt in Africa, lions are killed. But according to Mitman (1999) there is a general sentimentalisation of nature in American wildlife films after the 1940s. It seems as if a greater distance between man, on the one hand, and nature and animals, on the other, the more romantic Nature and the Animals become. The elk seems to be far too common and too 'close' in relation to Western man to qualify for admiring, romantic and sentimental accounts.

8. 'In female Lions, homosexual interaction is often initiated by one female pursuing another and crawling under her to encourage the other female to mount her. When mounting another female, a Lioness displayes a number of behaviors also associated with heterosexual mating, including gently biting the mountee on the neck, growling, making the pelvic thrust, and rolling on her own back afterward' (Bagemihl 1999: 433).

9. A clear exception concerning gender routine in the material is found in a film about the lions in Ngorongoro, which was shown on January 16, 1994 on SVT1. There the narrator points out that 'The role of the male is quite insignificant: he is supposed to look grand and handsome, keep other males away and impregnate the females. But in other respects he is a burden for the pride.'

\section{Literature}

Abrahamsson, Ulla B. (1999) I allmänhetens tjänst: Faktaprogram i radio och television 1955-1995. Värnamo: Stiftelsen etermedierna i Sverige.

Bagemihl, Bruce (1999) Biological Exuberance: Animal Homosexuality and Natural Diversity. London: Profile Books.

Bolter, Jay David \& Richard Grusin (2000) Remediation: Understanding New Media. Cambridge, Massachusetts: The MIT Press.

Bousé, Derek (2000) Wildlife Films. Philadelphia: University of Pennsylvania Press.

Bryld, Mette \& Nina Lykke (2000) Cosmodolphins: Feminist Cultural Studies of Technology. Animals and the Sacred, London \& New York: Zed Books.

Burt, Jonathan (2002) Animals in Film, vol. 1. London: Reaktion Books.

Butler, Judith (1990) Gender Trouble: Feminism and the Subversion of Identity. London \& New York: Routledge.

Butler, Judith (1993) Bodies that Matter: On the Discursive Limits of 'Sex'. London \& New York: Routledge.

Coates, Peter (1998) Nature: Western Attitudes since Ancient Times. Cambridge, Oxford: Polity Press. Franklin, Sarah, Celia Lury \& Jackie Stacey (2000) Global Nature, Global Culture. London: Sage.

Furhammar, Leif (1995) Med TV i verkligheten. Sveriges Television och de dokumentära genrerna. Borås: Stiftelsen etermedierna i Sverige. 
Haraway, Donna (1989) Primate Visions: Gender, Race and Nature in the World of Science. London \& New York: Routledge.

Keller, Evelyn Fox (1984) Reflections on Gender and Science. New Haven: Yale University Press.

Latour, Bruno \& Woolgar, Steve (1979/1986) Laboratory Life: The Construction of Scientific Facts. Princenton, N.Y: Princeton University Press.

Merchant, Carolyn (1980) The Death of Nature: Women, Ecology and the Scientific Revolution. New York: Harper \& Row.

Mitman, Gregg (1999) Reel Nature: America's Romance with Wildlife on Film. Cambridge, Massachusetts: Harvard University Press.

Nilsson, Per (2000) 'Svensk naturfilm skördar framgångar', in Metro November 3, 2000.

Robertson, George, Melina Mash, Lisa Tickner, Jon Bird, Barry Curtis \& Tim Putnam (eds.) FutureNatural: Nature, Science. Culture, London \& New York: Routledge.

Rothfels, Nigel (ed.) (2002) Representing Animals. Bloomington \& Indianapolis: Indiana University Press.

Said, Edward (1978/1991) Orientalism: Western Conceptions of the Orient. London: Penguin.

Snaprud, Per (2003) 'Apsex utmanar Darwins teori' in Dagens Nyheter, May 1, 2003.

Swedish Television's public service statement of accounts 2002', www.svt.se.

Vasey, Paul L. (1995) 'Homosexual Behavior in Primates: A Review of Evidence and Theory', in International Journal of Primatology, no. 16.

Schiebinger, Londa (1993) Nature's Body: Sexual Politics and the Making of Modern Science. London: Pandora.

Zuk, Marlene (2002) Sexual Selections: What We Can and Can't Learn about Sex from Animals. University of California Press: Berkeley. 


\section{Appendix}

\section{Index of Wildlife Films}

The completeness of the information about the different films varies and there seems to be no standard for what information is given before or after the broadcast of a film. Note that the year of broadcast is not the same as year of production, nor that it is certain that the dates below represent the first times of broadcast in Sweden.

\section{Lions}

January 1, 1979, 15.30-16.30, SVT1

Född till kung i djurriket: om lejon i Kenya [Born to Be King]

Director: Seido Hino

Photography: Kazu Matsumoto. Akira Kimura, Maremichi Matsui, Masahiko Takahashi, Shuuichi Kageyama

Editor: Fumio Kubooka

Music: Sadao Watanabe

Producer: Masaya Yoshikawa

Nippon Television Network Corp.

October 10, 1987, 18.30-19.30, SVT1

Ett med naturen: lejon i Afrikas natt [One with $\mathrm{Na}$ ture: Lions of the African Night]

Swedish narrator: Arne Weise

Photography: David \& Carol Hughes

Swedish translation: Sverre Sjölander

National Geographic

March 5, 1992, 20.00-21.00, SVT1

Ett med naturen: året med Khali, lejoninnan [One with Nature: Kali the Lion]

Swedish narrator: Arne Weise

Directed \& photographed by: Simon King

Film editors: Jonathan Birkett, Ian Wilson

Music: The people and animals of Masai Mara

Composed by: David Lowe

Produced by: Simon King

Lion consultant: Jonathan Scott

Swedish translation: Sverre Sjölander

$\mathrm{BBC}$

January 7, 1993, 20.00-21.00, SVT1

Jan Lindblad $i$ våra hjärtan. Ur djungelbokens värld: lejon (1980) [Jan Lindblad in Our Hearts: From the World of the Jungle Book]

Swedish narrator: Arne Weise

Photography etc: Jan Lindblad

Field assistant: Pia Thörn

January 16, 1994, 20.00-21.00, SVT1

Ett med naturen: Ngorongoros lejon [One with $\mathrm{Na}$ ture: Ngorongoro's Lions]

Swedish narrator: Arne Weise

Translation: Sverre Sjölander

Not other information available
March 25, 1997, 21.00-22.00, SVT2

Mitt $i$ naturen: Lejonet [In the Middle of Nature:

The Lion]

Swedish narrator: Lena Liljeborg

Photography: Owen Newman

Producers: Amanda Barret, Owen Newman

Editor: Stuart Napier

$\mathrm{BBC}$

May 10, 1998, 20.00-21.00, SVT1

Mitt $i$ naturen: Lejon $i$ nationalparken Etosha $i$ Namibia [In the Middle of Nature: The Lions in the National Park of Etosha in Namibia]

Swedish narrator: Charlotte Permell

Photography: Adrian Warren, Justin McGuire

Producer: Ann F. Kim

Music: Laura Karpman

Swedish Translation: Sverre Sjölander

March 21, 1999, 20.00-21.00, SVT1

Mitt $i$ naturen: Lejon $i$ Serengeti nationalpark, Tanzania [In the Middle of Nature: The Lions in the National Park of Serengeti, Tanzania]

Swedish narrator: Charlotte Permell

Photography: Sophie Buck

Producer: Patrik Morris

Swedish Translation: Sverre Sjölander

May 13, 2001, 20.00-21.00, SVT2

Mitt $i$ naturen: Systerskap på savannen - afrikanska lejon [In the Middle of Nature: Sisterhood on the Savannah - African Lions]

Swedish narrator: Charlotte Permell

Photographer/director: Barbara Tyack

Editor: Michael Holmes

Music: Ray Russel

Producer: Caroline Brett

Swedish Translation: Gunilla Bertili

Survival

March 31, 2002, 20.00-21.00, SVT2

Mitt i naturen: Lejonflocken inifrån [In the Middle of Nature: From Within a Group of Lions]

Swedish narrator: Charlotte Permell

Photography: Michael W. Richard \& Geoffrey Bell

Editor: Stuart Napier

Music: Will Gregory, Governors Camp Bush Band

\& The Maasai Dancers

Producer: John Downer

Swedish Translation: Jan-Åke Sääf

BBC 
Elk

May 30, 1994, 20.00-21.00, SVT1

Mitt $i$ naturen [In the Middle of Nature]

Feature: Amateur film about the elk as bedfellow (ca $15 \mathrm{~min}$ )

Photography: Helge Määtää

December 26, 1997, 10.00-10.15, SVT1

Älgen som går köksvägen [The Elk Who Comes in Through the Kitchen]

Script and director: Wilhelm Sörensen

A short film from Europa Film, 1959

July 30, 1997, 19.00-19.30, SVT1

Våra vilda djur: Älgen, a children's program [Our Wild Animals: The Elk]

Photography: Bertil Palmgren, Holger Jacobaeus

Music arrangement: Erik Baumann, Nathan Göring

Produced by: Arne Næva

Editing: Kjell Hartløv

NRK
May 16, 1999, 20.00-21.00, SVT1

Mitt $i$ naturen: De stora älgarna $i$ Sarek [In the Middle of Nature: The Great Elk of Sarek]

Narrator: Charlotte Permell

Director/photograph: Arne Nævra

Assistant producer/b-foto: Dagfinn Kolberg

Music: Halvdan Nedre

Sound: Helge Holmen

Light: Trygve Andresen

Funding: Nordisk film och TV-fond, in co-operation with SVT, DR, YLE, NRK 1 - Naturredaktionen 1998 